\title{
The emergence of a tradition: Technical writing in the English Renaissance 1475-1640
}

\author{
By Nadeane Trowse \\ $U B C /$ University College of the Fraser Valley
}

\begin{abstract}
Elizabeth Tebeaux. The Emergence of a Tradition: Technical Writing in the English Renaissance 1475-1640, Amityville, New York, Baywood Publishing, 1997.
\end{abstract}

Elizabeth Tebeaux's book The Emergence of a Tradition: Technical Writing in the English Renaissance 1475-1640 demonstrates that technical writing as a kind of text, as one type of social means for the distribution of information, has a rich history. Tebeaux presents the early modern ancestors of today's "how to" guides, medical manuals, and plant identification guides. Teachers and students of technical writing, working in a discipline that may sometimes feel like a continually emerging discipline, will likely appreciate Tebeaux's work, as she writes technical writing and its scholars into an historical continuum, reinscribing both practitioners and the discipline itself. But such appreciative readers might wish, too, for the insights that would have been provided had Tebeaux situated her discussion of the sociality of the texts and the emergence of technical writing more firmly in current ongoing discussions of the sociality of texts and their formal, situated constraints.

Tenebeaux indicates that her book is a response to Michael Moran's challenging claim: "the history of technical writing has not been written" (Moran, 1986, p. 25). Tebeaux offers such a history, at least for the technical writing occurring in England between 1475 and 1640 . The texts she examines occupy a significant and highly varied spectrum of English history, from Caxton's printing press to the beginning of the English civil wars between Royalists and supporters of the Commonwealth. She tracks the evolution of technical writing as it keeps step with the evolution and acceleration of text dispersal by means of printing technologies. Tebeaux's overarching finding seems to be that the accelerating move from orality to literacy fostered by the printing press and the social realities that generated it were transformative of text, of text type, of society. In her words: 
Literacy transformed technical writing; technology emerged from knowledge; printing reshaped how work was perceived in medicine, agriculture, and military science, and ultimately, literacy and print nurtured each others. (pp. 238-239)

Before discussing what Tebeaux offers in her seven chapters, it is worth noting that she explicitly states that her book is organized by principles which inform technical writing, and moreover that each chapter is intended to function as an independent, self-explanatory unit. This has the effect of making each chapter convenient for use in teaching; chapters can be assigned individually without risking incoherence. This too has the effect of creating some readerly dissonance: the sense of reencountering in subsequent chapter information presented as if for the first time. Further, the occasional use of technical writing point-form-like presentation tends to sound unlike the writing of the discipline of history, yet Tebeaux juxtaposes such presentation with more usual features of academic writing.

Tebeaux's first chapter situates her discussion of technical writing in the English Renaissance period, focussing on issues of text production, text use, text design, and text style with the historical socio-economic analysis that pursuing these issues implies. She also notes that technical writing is epistemic, as it both makes and distributes knowledge. Overall, her expressed goal is to "see through technical books what tasks were important in English life, how this work was performed, what constituted 'work,' and why specific tasks were valued" (p. 3). Thus, her work on what she terms technical or instructional books turns the focus away from the literary writers of the period like Shakespeare and draws her readers' attention to the texts of the "common man."

Her second chapter, which begins by attributing the rise of technical books in the English Renaissance to the simultaneous growth of wealth, knowledge, education, trade, and humanism details the types of technical writing that are her main concern. These include books on how to identify, understand, and perform selected activities of daily life: food production including farming, animal husbandry, and gardening; books on diseases, medical diagnoses, and treatments including drugs and surgery; books on household management and cooking; books on recreations including hunting, fishing, hawking, horsemanship; books on the arts related to trade and to military science including navigation. She offers intriguing images of pages from an assortment of such books which whet the reader's appetite for more such images to examine. 
In chapter three, Tebeaux seeks to show how what she now comes to call "books of instruction" are visually/physically distinct from other (religious or literary) printed texts of the day. The "how to" books, unlike the liturgical/religious work and popular histories and literature in print in this time period, are designed, not for sustained reading, but for quick reference. To facilitate speed of access, such books of instruction have features we now associate with technical writing. They feature indexes, headings, easily-read roman rather than script type-face, portability (pocket-sized), and general organizational and graphic principles Tebeaux attributes to the use of the principles of Ramist rhetoric.

In chapter 4 Tebeaux discusses the make-up of the audience for these technical books and notes that the technical or instructional book's audience was also its market. The technical book, indeed printing as a whole at this time, is connected by Tebeaux with the profit motive. She contends that this profit motive inspired an expanded sense of that market for book producers. Books for the elite and the wealthy continued to be made at this time, but books for a populace with lower levels of literacy and lighter purses but with a desire for instruction were also produced. As well, Tebeaux distinguishes expert from general audiences as distinct markets for instructional books. She notes that this mixed market lead to the useful practice of including with Latin text an English translation. She makes the point that some books and their authors addressed the problem of audience by devoting different sections to different audiences, while others were single-audience focused but sometimes existed in different versions on the same topic for different audiences. She makes the point that some individual authors simultaneously wrote works of literature and works on religion, as well as technical books, an important point whose significance she does not explore.

In chapter five, Tebeaux links the development of early modern technical/instructional writing with the emergence of English plain style (as distinct from the florid Elizabethan literary style), debunking the usual explanation of plain style as a result of the development of science writing. Tebeaux continues to link Ramus rhetoric (discussed in chapter three) with the "clarity" that is a prime feature of plain style. Such talk about clarity exemplifies certain persistent and problematic aspects of the talk about language-use which are still with us in the "complaint tradition" model that James Milroy and Lesley Milroy (1985) describe. Tebeaux's discussion of Ramus's influence is thus perhaps too simplified or familiar, resonating with typical advice given to students in technical writing guides simply "to be clear." This unproblematized view of clarity misses necessary nuances about the socially situated 
nature of clarity. Certainly the words on the pages of the early texts Tebeux displays are "clearer" (i.e. literally more easily read) than liturgical texts of the period, but in fact their socially situated meaning may be far less clear to a present day reader.

Chapter six further discusses visual and verbal print presentation as it is connected to the early modern movement from orality to textuality: "the increasingly integrated verbal and visual presentation of objects and concepts ... molded into text" (p. 176). This chapter begins by setting an unresolved puzzle for the reader. While Tebeaux suggest that "...the emergence of technical writing was dependent upon forces other than advancements in typography" (p.175), on the following page she includes just such typographical advancements as the second point in her list of combining factors that precisely supported the emergence of technical writing. The need for technical description to accompany technical illustration is seen by Tebeaux at any rate as the main motivator of such writing. This chapter offers further insight into the movement between early modern writing and illustration in England and methods adopted from the Italian renaissance, which, Tebeaux suggests, were brought to England by "those who plagiarised Vesalius" (p. 192).

Tebeaux's brief concluding chapter reiterates the importance of acknowledging that technical writing is rooted in the English renaissance, or early modern period. She concludes by hoping that her work particularly will instigate further inquiry, resulting in more precise definitions of technical writing, more work on the rhetoric of technical writing, specific stylistic analysis of specific types of technical books, and investigations of how technical books made meaning in their socially constructed contexts.

Overall, while I find Tebeaux's examples of historic texts (particularly the reproduction of pages from them that she includes) compelling, I find her analysis of the texts and their activity a bit sparse. The scholarship she cites is mostly historical; while she advocates it, Tebeaux makes little use of social-construction theory. In particular, I note that her use of the term "genre" is mainly classificatory and bears little traces of an awareness of the richness of work like that generated by Carolyn Miller's thinking and subsequent theorists like Anthony Paré or Janet Giltrow who consider New Rhetorical Genre theory or activity theory useful approaches to understanding texts as necessarily socio-cognitively situated and constructed. 